\title{
Biliary tract neoplasms: detection and staging CT and Ultrasound
}

\author{
Richard M Gore*, Robert I Silvers \\ From International Cancer Imaging Society (ICIS) 14th Annual Teaching Course \\ Heidelberg, Germany. 9-11 October 2014
}

Most biliary tract neoplasms are malignant and have been traditionally divided into cancers of the gallbladder, the extrahepatic bile ducts, and ampulla of Vater. Although infrequent, bile duct carcinomas and cancer of the gallbladder are not rare. In the United States, an estimated 6,000 to 7,000 new cases of carcinoma of the gallbladder and 3,000 to 4,000 new cases of carcinoma of the bile ducts are diagnosed annually. Familiarity with the imaging characteristics of gallbladder and bile duct neoplasms is important to expedite diagnosis and appropriate treatment of patients who often present with nonspecific symptoms of right upper quadrant pain, jaundice, and weight loss. This workshop presents the CT and ultrasound features of biliary tract neoplasms important for early diagnosis, staging, and follow-up of these often lethal neoplasms

Published: 9 October 2014

* Correspondence: rgore@uchicago.edu

Department of Radiology, North Shore University Health System, University of Chicago, Pritzker School of Medicine, Evanston, IL USA

Submit your next manuscript to BioMed Central and take full advantage of:

- Convenient online submission

- Thorough peer review

- No space constraints or color figure charges

- Immediate publication on acceptance

- Inclusion in PubMed, CAS, Scopus and Google Scholar

- Research which is freely available for redistribution

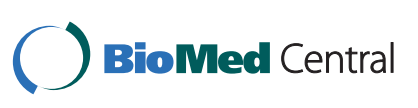

(c) 2014 Gore and Silvers; licensee BioMed Central Ltd. This is an Open Access article distributed under the terms of the Creative Commons Attribution License (http://creativecommons.org/licenses/by/4.0), which permits unrestricted use, distribution, and reproduction in any medium, provided the original work is properly cited. The Creative Commons Public Domain Dedication waiver (http://creativecommons.org/publicdomain/zero/1.0/) applies to the data made available in this article, unless otherwise stated. 